\title{
Non-contrast quantitative T1-mapping indicates that salvaged myocardium develops edema during coronary occlusion, whereas infarction exhibits evidence of additional reperfusion injury
}

\author{
Martin Ugander ${ }^{1 *}$, Micheas Zemedkun ${ }^{1}$, Li-Yueh Hsu' ${ }^{1}$, Abiola J Oki ${ }^{1}$, O Julian Booker ${ }^{1}$, Peter Kellman', \\ Andreas Greiser ${ }^{2}$, Anthony H Aletras ${ }^{1}$, Andrew E Arai ${ }^{1}$
}

From 2011 SCMR/Euro CMR Joint Scientific Sessions

Nice, France. 3-6 February 2011

\section{Introduction}

$\mathrm{T} 2$-weighted cardiovascular magnetic resonance (CMR) can characterize myocardial edema in acutely infarcted myocardium and in recently ischemic but salvaged myocardium in ways that are distinct and complementary to late gadolinium enhanced (LGE) images. If T2 can be used to detect myocardial edema, then non-contrast T1 quantification may also be abnormal in a similar fashion.

\section{Purpose}

To quantitatively assess if salvaged myocardium develops edematous changes during coronary occlusion, but not reperfusion injury as can be seen in infarction.

\section{Methods}

Dogs $(\mathrm{n}=9)$ underwent coronary occlusion and reperfusion to delineate the time course of development of changes in non-contrast $\mathrm{T} 1$ abnormalities. T1 was quantified by 1.5T CMR (Siemens) using a Modified LookLocker Inversion Recovery (MOLLI) sequence. T2prepared SSFP (T2p) and LGE images were acquired at the end of the experiment to define 1) Infarction [LGE positive], 2) Salvaged myocardium [T2 $p$ positive and LGE negative] and 3) Remote [T2p and LGE negative]. Myocardium which ultimately ended being classified into these three tissue types was identified, and T1 was quantified over time starting from baseline prior to occlusion.

${ }^{1}$ National Institutes of Health, Bethesda, MD, USA

Full list of author information is available at the end of the article

\section{Results}

See Figure 1. During occlusion, T1 increased in tissue which ultimately became Infarction or Salvaged $(p<0.01$ for both), and to a greater extent in tissue which ultimately became Infarction compared to Salvaged $(p=0.03)$. Within 30 minutes of reperfusion, $\mathrm{T} 1$ of Infarction increased further $(\mathrm{p}=0.001)$, whereas $\mathrm{T} 1$ of Salvaged myocardium remained unchanged after reperfusion $(\mathrm{p}=0.73)$.

\section{Conclusions}

Coronary occlusion leads to an increase in non-contrast $\mathrm{T} 1$, consistent with edema, both in tissue which ultimately will become infarcted, and in tissue which

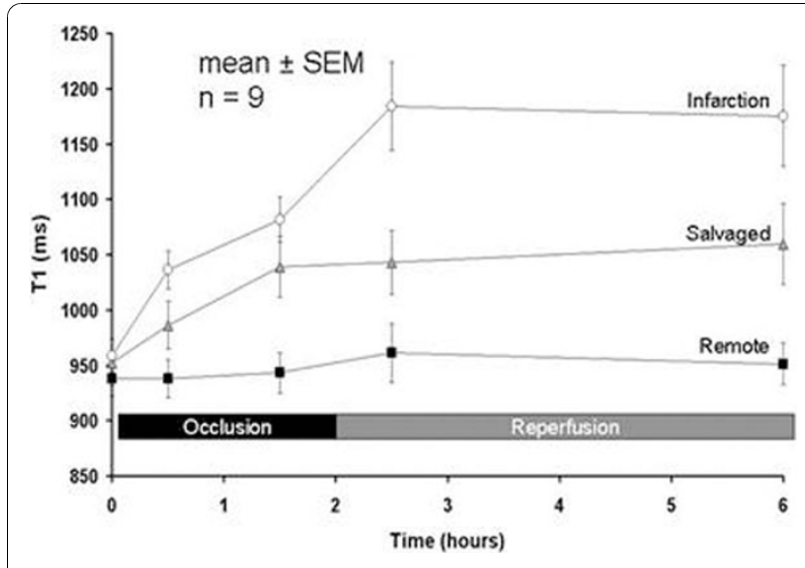

Figure 1 Time course of non-contrast T1 values during occlusion and reperfusion for myocardium which ultimately will become infarcted, salvaged and remote. 
ultimately will be salvaged. The increase in T1 during occlusion is more pronounced, consistent with more severe ischemia, in tissue which ultimately will become infarcted compared to that which becomes salvaged. Following reperfusion, only the tissue which becomes infarcted, but not that which becomes salvaged, increases additionally in $\mathrm{T} 1$, and this is consistent with reperfusion injury in infarcted myocardium.

Author details

${ }^{1}$ National Institutes of Health, Bethesda, MD, USA. ${ }^{2}$ Siemens AG Healthcare Sector, Erlangen, Germany.

Published: 2 February 2011

doi:10.1186/1532-429X-13-S1-063

Cite this article as: Ugander et al:: Non-contrast quantitative T1-

mapping indicates that salvaged myocardium develops edema during coronary occlusion, whereas infarction exhibits evidence of additional reperfusion injury. Journal of Cardiovascular Magnetic Resonance 201113 (Suppl 1):063.

Submit your next manuscript to BioMed Central and take full advantage of:

- Convenient online submission

- Thorough peer review

- No space constraints or color figure charges

- Immediate publication on acceptance

- Inclusion in PubMed, CAS, Scopus and Google Scholar

- Research which is freely available for redistribution

Submit your manuscript at www.biomedcentral.com/submit 